\title{
MODAL SOSIAL DAN KEBERLANJUTAN KELEMBAGAAN DALAM PROGRAM CSR PT TIRTA INVESTAMA DI KABUPATEN CIANJUR JAWA BARAT
}

\author{
(Social Capital and Institutional Sustainability of \\ PT Tirta Investama CSR Program in District of Cianjur)
}

\author{
Chinthia $^{1)}$ dan Fredian Tonny Nasdian ${ }^{1)}$ \\ 1) Departemen Sains Komunikasi dan Pengembangan Masyarakat, Fakultas Ekologi Manusia, \\ Institut Pertanian Bogor, Darmaga Bogor 16680, Indonesia \\ E-mail: sinsganesha@gmail.com; frediantonny@apps.ipb.ac.id
}

\begin{abstract}
Corporate social responsibility is a responsibility that must be implemented by the company to the public and the environment. Social capital, especially social networks have a role in the sustainability of institutions in Cianjur District, West Java. The main objective is create a sustainable program, that keep continued even though the company is no longer or not directly involed. This study aims to describe social networks, social capital, institutional sustainability, and analyze the correllation between social networks and institutional sustainability. This study uses quantitative approach with census method supported by qualitative data. The results showed that the level of social networking contained in HIPOCI were on a broad level and the level of institutional sustainability in high level. Based on the research that has been tested statistically show that there is a correlattion between the level of social networking with the level of institutional sustainability.
\end{abstract}

Key words: social networks, typology, correlation

\begin{abstract}
ABSTRAK
CSR atau tanggung jawab sosial perusahaan merupakan bentuk tanggung jawab yang wajib dilaksanakan oleh perusahaan kepada masyarakat dan lingkungan sekitar. Modal sosial, khususnya jejaring sosial memiliki peranan dalam keberlanjutan kelembagaan di Kabupaten Cianjur, Jawa Barat. Hal ini diharapkan mampu menjadikan suatu program dapat berkelanjutan meskipun perusahan tidak lagi ikut terlibat. Penelitian ini bertujuan untuk memaparkan jejaring sosial, modal sosial, keberlanjutan kelembagaan, menganalisis hubungan jejaring sosial dan keberlanjutan kelembagaan. Penelitian ini menggunakan pendekatan kuantitatif didukung data kualitatif dengan metode sensus. Hasil penelitian menunjukkan tingkat jejaring sosial yang terdapat pada HIPOCI berada di tingkat luas dan tingkat keberlanjutan kelembagaan di tingkat tinggi. Berdasarkan hasil uji secara statistik menunjukkan bahwa terdapat hubungan antara tingkat jejaring sosial dengan tingkat keberlanjutan kelembagaan.
\end{abstract}

Kata kunci: jejaring sosial, tipologi, korelasi

\section{PENDAHALUAN}

Pembangunan berkelanjutan merupakan tujuan perusahaan dalam membuat program CSR. Pembangunan yang memprioritaskan ekonomi dinilai sudah tidak lagi efektif. Hal ini diperkuat dari berbagai penelitian yang menunjukan pembangunan ekonomi tidak diimbangi dengan pembangunan lainnya seperti sosial dan ekologi bernilai negatif. Konsep pembangunan berkelanjutan menjadi topik yang menarik untuk diteliti, konsep ini kembali diperbincangkan pada Tahun 1987 ketika World Commission on Environment and Development (WCED) menerbitkan buku Our Common Future yang 
membahas tentang konsep pembangunan ekonomi dan keterkaitannya dengan lingkungan dalam konteks pembangunan berkelanjutan. Pembangunan yang terlihat signifikan merupakan pembangunan ekonomi yang relatif lebih tinggi dibandingkan dua bidang lainnya, sosial dan lingkungan (Fauzi dan Oxtavianus 2014). Pembangunan yang terus meningkat, di lain hal memiliki dampak yang signifikan di lingkungan sekitarnya. Pembangunan industri di bidang eksploitasi sumberdaya alam seringkali menimbulkan dampak kerusakan lingkungan. Korporat pada saat ini memiliki tantangan yang lebih berat karena penyelesaian masalah bukan sekedar memberi materi, melainkan perlunya pengembangan ekonomi dan keterkaitannya dengan lingkungan dalam konteks pembangunan berkelanjutan (Fauzi dan Oxtavianus 2014). Program CSR yang telah diimplimentasi diharapkan mampu menjadikan masyarakat disekitar mandiri dan meneruskan program setelah program berakhir.

Indonesia merupakan negara satu-satunya yang mengatur CSR di dalam Undang-undang. Undang-undang No. 40 Tahun 2007 Tentang Perseroan Terbatas mewajibkan semua perseroan terbatas menjalankan kegiatan usahanya di bidang dan/atau berkaitan dengan sumberdaya alam untuk melaksanakan tanggung jawab dan lingkungan. Menurut ISO 26000, CSR adalah bentuk tanggung jawab organisasi terhadap dampak dari keputusan dan aktivitas organisasi terhadap masyarakat serta lingkungan, melalui perilaku yang transparan dan etis yang memberikan kontribusi untuk pembangunan keberlanjutan, kesehatan, kepentingan; sejalan dengan hukum yang berlaku dan sesuai dengan norma-norma universal; dan terintegrasi dengan hukum yang berlaku dan sesuai dengan normanorma universal; dan terintegrasi di seluruh organisasi dan dipraktikkan dalam hubunganhubungannya. Suatu program dapat dikatakan berkelanjutan yaitu sudah dijalankan lebih dari satu tahun dan sudah terdapat manfaat/hasil nyata, atau kegiatan serta manfaatnya tetap berlanjut meskipun perusahaan tidak lagi terlibat.

HIPOCI (Himpunan Petani Organik Cianjur Indonesia) merupakan kelompok tani lokal yang berdiri karena tekad yang kuat untuk maju di bidang pertanian. Pembentukan HIPOCI berawal dari program Integrative Farming System (IFS) oleh PT Tirta Investama. Perusahaan bersama dengan masyarakat mendiskusikan program sesuai dengan kebutuhan. Masyarakat di Kecamatan Gekbrong mengusulkan untuk membentuk lembaga yang berbeda. HIPOCI terbentuk sebagai lembaga resmi yang disahkan di Pengadilan Negeri Cianjur dengan nomor: W11. U11. PR7610.01/III/2012. Kecamatan Gekbrong memiliki total luas sawah 1.254,400 ha. Kecamatan Gekbrong merupakan kecamatan yang berdekatan dengan PT Tirta Investama menjadi alasan program diimplementasikan. Sistem pertanian organik diterapkan oleh petani untuk berpartisipasi dalam program pemerintah, yaitu Go Green. Kehadiran HIPOCI mampu mempererat hubungan individu dengan organisasi dan organisasi dengan organisasi karena keterikatan yang telah dijalin.

Menurut Lubis (2012) yang dikutip Nasdian (2014) Networking menjadi komponen penting dalam pengembangan jaringan sosial. Penelitian ini menyebutkan tanggung jawab perusahaan yang diterapkan oleh PT Tirta Investama berupa pembentukan kelembagaan ekonomi pertanian yaitu, HIPOCI. Program CSR akan berhasil berkembang apabila kelembagaan berjalan sustainable. Oleh karena itu, menarik bagi penulis untuk meneliti Bagaimana peran modal sosial dalam keberlanjutan kelembagaan?

Program HIPOCI merupakan kebutuhan masyarakat akan lembaga yang bertujuan pada pertanian sehat. HIPOCI menjalin kerjasama guna meningkatkan produksi dan pemasaran produk pertanian. HIPOCI menjalin kerjasama dengan perusahaan sebagai awal mula jaringan lainnya terbentuk demi keberlangsungan kelembagaan. Jaringan sosial berfokus pada aspek ikatan antara simpul berupa individu maupun kelompok (organisasi). Buku Membangun Jaringan Sosial dan kemitraan yang dikeluarkan oleh Kementrian Desa, Pembangunan Daerah Tertinggal, dan Transmigrasi jaringan sosial (Arsyad 2015) diharapkan mampu mengoptimalkan proses pembangunan dan pola pemberdayaan desa yang umumnya ketergantungan. Maka dari itu, muncul lah pertanyaan bagaimana jaringan sosial dari perspektif modal sosial Himpunan Petani Organik Cianjur Indonesia (HIPOCI)? 
Sustainable development memerlukan adanya sinkronisasi ketiga dimensi dalam pembangunan berkelanjutan, yaitu dimensi ekonomi, dimensi sosial, dan dimensi lingkungan. CSR memiliki tantangan untuk menjawab permasalahan masyarakat dengan tidak melihat dari sisi profit. Untuk mencapai sustainable development perlu adanya sinkronisasi ketiga dimensi dalam pembangunan berkelanjutan, yaitu dimensi ekonomi, dimensi sosial, dan dimensi lingkungan. CSR menurut ISO 26000 memiliki bentuk tanggung jawab melihat pada terintegrasinya organisasi dan hubunganhubungannya untuk pembangunan berkelanjutan. Korten dan Klauss (1984) mengatakan bahwa keberlanjutan tidak berfokus pada produksinya, melainkan memberi peran masyarakat itu sendiri. Pertanyaan kedua peneliti adalah bagaimana keberlanjutan kelembagaan Himpunan Petani Organik Cianjur Indonesia (HIPOCI)?

Jejaring sosial petani terjalin dengan level yang berbeda. Jejaring sosial yang terjalin memiliki tujuan dalam mendapatkan informasi dan pengetahuan baru. Hal ini menjadikan petani mampu menyelesaikan permasalan yang dihadapi dalam pertanian. Petani yang bergabung dalam kelembagaan memiliki akses kepada jaringan lebih luas. HIPOCI menjalin jejaring sosial guna membantu kelembagaan tetap berdiri. HIPOCI menjalin kerjasama dalam produksi pertanian dan pemasaran. Kelembagaan yang dikembangkan oleh kelompok diharapkan akan mendorong kemandirian dan berkembang secara berkelanjutan. Pertanyaan ketiga peneliti adalah bagaimana hubungan jejaring sosial dengan keberlanjutan kelembagaan?

Berdasarkan identifikasi masalah yang telah disampaikan sebelumnya, maka tujuan penelitian dirumuskan sebagai berikut: 1) Menganalisis jejaring sosial HIPOCI. 2) Menganalisis keberlanjutan kelembagaan HIPOCI. 3) Menganalisis hubungan jejaring sosial dalam keberlanjutan kelembagaan HIPOCI.

\section{PENDEKATAN TEORITIS}

\section{Modal Sosial}

Konsep modal sosial masih dipandang sebelah mata dalam penentuan program. Modal sosial yang dimiliki oleh masyarakat dapat dijadikan kekuatan seperti hubungan dengan kegiatan bersama, kelompok, dan bergotong royong. Program-program CSR yang baik merupakan yang mampu menjadikan masyarakat mandiri bahkan saat program sudah tidak lagi terlibat. Masyarakat memiliki kemampuan untuk bekerjasama yang terlihat jelas di Indonesia dengan istilah gotong royong. Modal sosial menurut Coleman (1999) adalah kemampuan masyarakat untuk bekerja sama, demi mencapai tujuan-tujuan bersama, di dalam berbagai kelompok dan organisasi. Menurut Cox (1995) dalam masyarakat yang memiliki tingkat kepercayaan yang tinggi, aturan-aturan sosial cenderung bersifat positif dan saling bekerjasama.

\section{Jejaring Sosial}

Putnam (1993) mengatakan bahwa jaringanjaringan sosial yang erat akan memperkuat perasaan kerjasama para anggotanya serta manfaat-manfaat partisipasinya. Jaringan sosial yang luas mampu memberikan kontribusi dalam aktivitas ekonomi masyarakat. Bourdieu (1986) menjelaskan modal sosial fokus pada individu dan menyatakan bahwa modal sosial terdiri dari jaringan sosial yang membantu individuindividu untuk mendapatkan akses pada sumberdaya yang dimiliki oleh aktor-aktor lain dalam jaringan tersebut.

Jejaring sosial memiliki peran dalam mengakses kebutuhan. Jaringan dapat diakses dengan hubungan antar keluarga, kerabat, dan di luar kekerabatan. Jejaring yang dijalin dapat mengikat, menyambung, maupun mengubungkan. Adapun tipologi modal sosial menurut Woolcock (2001), yaitu:

\section{Mengikat (bonding)}

Modal sosial ini memiliki ciri khas kelompok ataupun anggota kelompok yang umumnya homogen. kelompok homogen ini umumnya berasal dari suku yang sama yang fokusnya pada upaya menjaga nilai-nilai yang turun menurun telah diakui dan dijalani sebagai bagian dari tata perilaku (code of conducts) dan perilaku moral (code of ethics) dari suku atau entitas sosial tersebut. Mereka cenderung mengutamakan solidarity making daripada hal-hal yang lebih nyata untuk membangun diri dan kelompok sesuai dengan tuntutan nilai-nilai dan norma 
masyrakat yang lebih terbuka (Hasbullah 2006).

\section{Menyambung (bridging)}

Berbeda dengan bonding, bridging memiliki sifat yang inklusif dan berorientasi ke luar (outward looking). Coleman (1999) menganggap bahwa masyarakat ini cenderung menciptakan jaringan ke luar sehingga mampu bekerjasama dengan kelompok di luar mereka. Pada masyarakat ini walaupun hubungan sosial yang tercipta memiliki tingkat kohesivitas yang kuat, tetapi tidak merefleksikan kemampuan masyarakat tersebut untuk menciptakan dan memiliki modal sosial yang kuat. Kemajuan pada kelompok ini akan lebih mudah dicapai karena pertukaran ide akan terus berkembang dan menstimulasi perkembangan kelompok dan individu kelompok tersebut.

\section{Menghubungkan (Linking)}

Social Linking (hubungan/jaringan sosial) merupakan hubungan sosial yang dikarakteristikkan dengan adanya hubungan di antara beberapa level dari kekuatan sosial maupun status sosial yang ada dalam masyarakat. Misalnya: Hubungan antara elit politik dengan masyarakat umum. Dalam hal ini elit politik yang dipandang khalayak sebagai /tokoh, dan mempunyai status sosial daripada masyarakat kebanyakan. Namun mereka sama-sama mempunyai kepentingan untuk mengadakan hubungan. Elite politik membutuhkan massa untuk mendapatkan suara dan mendukungnya. Sementara masyarakat berusaha mendapatkan orang yang dipercaya bisa menjadikan penyalur aspirasi dan yang mereka percayai sebagai wakilnya.

\section{Corporate Social Responsibility (CSR)}

CSR menurut ISO 26000 adalah bentuk tanggung jawab organisasi terhadap dampak dari keputusan dan aktivitas organisasi terhadap masyarakat serta lingkungan, melalui perilaku yang transparan dan etis yang memberikan kontribusi untuk pembangunan berkelanjutan, kesehatan, dan kesejahteraan masyarakat; turut mempertimbangkan pemangku kepentingan; sejalan dengan hukum yang berlaku dan sesuai dengan norma-norma universal; dan terintegrasi di seluruh organisasi dan dipraktikkan dalam hubungan-hubungannya.

CSR berkembang pada Tahun 1990-an dengan ditandai munculnya definisi CSR oleh WBSD (World Business Council for Sustainable Development). Sebuah lembaga yang yang bentuk oleh PBB (Perserikatan Bangsa-Bangsa) untuk kalangan bisnis agar dapat berkontribusi dalam pembangunan. Suatu konsep yang menjadi impian masa depan adalah pembangunan tanpa merusak sumberdaya alam dan mencoba menyatukan elemen lainnya yaitu sosial dan ekonomi. Perusahaan dalam menentukan program tentu harus memahami bagaimana pola masyarakat sekitarnya. Sehingga mampu mengembangkan kesejahteraan masyarakat. Hal ini berkaitan dengan tujuan dari pembangunan masyarakat yang mengarah pada partisipatif. Konsep Keberlanjutan Kelembagaan

Korten dan Klauss (1984) berpendapat tentang "production centered development" bahwa pendekatan pembangunan yang berpusat pada produksi. Masyarakat di kontrol secara terpusat dan bersifat sentralisasi. Sehingga kebijakan pembangunan hanya berpihak kepada konsumen, penduduk kelas menengah perkotaan, dan meminggirkan produsen. Maka dari itu, pembangunan berorientasi pada ekonomi harus ditinggalkan menuju pembangunan yang baru. Pembangunan dikembangkan yaitu ekologi manusia yang seimbang dengan sumberdaya utama berupa daya informasi dan prakarsa kreatif dengan memberi peran kepada masyarakat. Paradigma ini dikenal sebagai "people centered development".

Dalam buku Nasdian (2014) membahas keberlanjutan program CSR dan keberlanjutan kelembagaan. Hasil analisis studi 12 desa binaan ini menunjukan bahwa sangat potensial apabila strategi penguatan kelembagaan "menghubungkan" kebutuhan warga komunitas dengan kebijakan perusahaan dan stakeholder lainnya mendayagunakan kekuatan tokoh masyarakat lokal baik di aras komunitas desa maupun aras "atas" komunitas desa yang memiliki kekuatan modal sosial dan modal budaya.

Berdasarkan konsep yang telah dipaparkan dapat disimpulkan bahwa pembangunan yang berfokus 
pada profit akan merusak sumberdaya alam karena eksploitasi yang meningkat. Pembangunan yang baik fokus pada tiga elemen pembangunan, yaitu ekonomi, manusia, dan lingkungan. Elemen manusia perlu dibangun untuk kesadaran dalam menjaga lingkungan agar tetap lestari tanpa menghilangkaan elemen ekonomi.

Tingkat keberlanjutan CSR diukur dengan sejauh mana keberlanjutan program-program CSR dan keberlanjutan kelembagaan CSR, faktor-faktor yang menentukan keberlanjutan program dan kelembagaan CSR (Nasdian 2014) adalah:

\section{Kapasitas Kelembagaan}

Kapasitas kelembagaan menurut penelitian Anantayu (2009), dapat tercapai dengan melihat indikator, yaitu: 1) Tujuan kelembagaan kelompok, adanya kesesuaian tujuan dengan kebutuhan anggota, dan tingkat pemenuhan kebutuhan anggota. 2) Fungsi dan peran kelembagaan berjalan, meliputi: adanya kemampuan memperoleh, mangatur, memelihara, dan mengarahkan informasi, tenaga kerja, modal dan material, serta kemampuan mengelola konflik. 3) Adanya keinovatifan kelembagaan, meliputi: adanya peran kepemimpinan dalam kelembagaan, fungsi kepemimpinan dalam kelembagaan, adanya nilai-nilai yang mendasari kerjasama, adanya pembagian peran anggota.

\section{Insentif Kelembagaan}

Mangkunegara (2001) mengatakan bahwa insentif adalah suatu penghargaan dalam bentuk uang yang diberikan oleh pihak pemimpin organiasai kepada karyawan agar mereka bekerja dengan motivasi yang tinggi dan berprestasi dalam mencapai tujuan-tujuan organisasi. Hasibuan (1990) ada dua bentuk insentif yaitu insentif material dan insentif non material. (a) Insentif material adalah sebuah imbalan prestasi yang diberikan, yang termasuk dalam upah, barang, dan sejenisnya. segala daya perangsang yang dapat dinilai dengan uang. (b) Insentif non material adalah penempatan yang tepat, latihan yang sistematis, program penghargaan, dan bintang jasa.

\section{Perencanaan Bersama}

Perencanan partisipatif merupakan salah satu proses pembelajaran bagi masyarakat. Pembelajaran ini mendukung masyarkat untuk sadar akan situasi yang mereka hadapi dan mencari jalan keluar dari permasalahan secara kritis (Nasdian 2014). Perencanaan partisipatif memiliki arti menekankan partisipatif luas dari stakeholder dalam proses perencanan dan pengambilan keputusan dalam pembangunan (Suratman 2008).

\section{Kerangka Pemikiran}

Menurut Lubis (2012) yang dikutip Nasdian (2014) Networking menjadi komponen penting dalam pengembangan jaringan sosial.

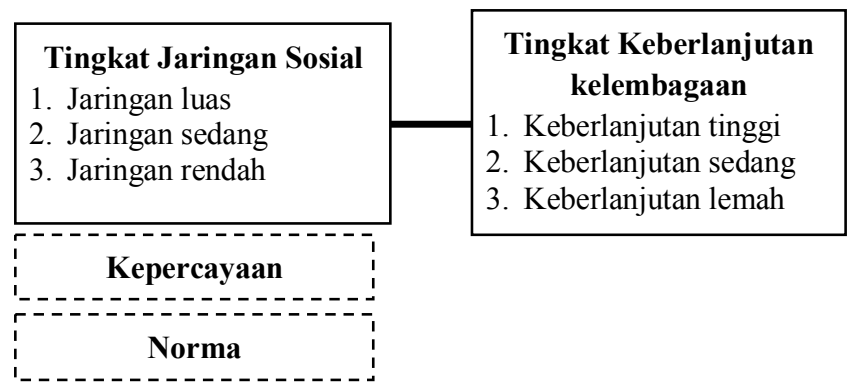

Keterangan:

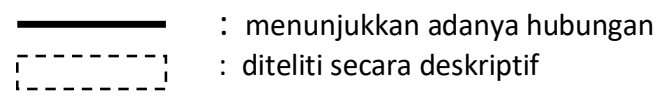

Gambar 1 Kerangka Analisis Penelitian

Penelitian ini menyebutkan tanggung jawab perusahaan yang diterapkan oleh PT Tirta Investama berupa pembentukan kelembagaan ekonomi pertanian yaitu, HIPOCI. Program CSR akan berhasil berkembang apabila kelembagaan berjalan berkelanjutan (sustainable). Untuk melihat keberlanjutan program CSR dan kelembagaan, Nasdian (2014) di dalam bukunya menyebutkan faktor-faktor yang menentukannya adalah (a) kapasitas keberlanjutan; (b) instentif kelembagaan; dan yang terakhir (c) partisipasi bersama. Gambar 1 merupakan kerangka analisis penggabungan dari pustaka yang digabungkan, kerangka ini menunjukan keterkaitan antar variabel yang dijelaskan penulis dalam pustakanya. 


\section{Hipotesis}

Hipotesis dalam penelitian ini adalah semakin luas tingkat jaringan sosial maka semakin tinggi keberlanjutan kelembagaan.

\section{METODE PENELITIAN}

Pendekatan penelitian yang digunakan adalah pendekatan kuantitatif didukung dengan data kualitatif. Pendekatan kuantitatif dilakukan dengan cara sensus, yaitu penelitian yang mengambil semua populasi dengan menggunakan kuesioner sebagai alat pengumpul data primer. Data kualitatif diperoleh peneliti dengan melakukan FGD kepada responden dan wawancara mendalam kepada informan menggunakan panduan pertanyaan untuk memahami secara mendalam dan rinci mengenai suatu peristiwa, serta dapat menggali berbagai realitas, proses sosial, dan makna yang berkembang dari orang-orang yang menjadi subjek penelitian.

Pemilihan lokasi dilakukan secara purposive (sengaja) yaitu di Kecamatan Gekbrong dan Kecamatan Warungkondang. Waktu pelaksanaan penelitian berlangsung mulai September 2016 hingga Januari 2017.

Terdapat dua subjek dalam penelitian ini yaitu informan dan responden. Responden adalah individu yang dapat memberikan keterangan atau informasi mengenai dirinya sendiri. Populasi penelitian ini adalah anggota HIPOCI. Unit analisis dalam penelitian ini adalah individu, yaitu anggota petani organik HIPOCI. Metode penelitian yang digunakan adalah sensus dengan jumlah populasi sebanyak 25 orang.

Pemilihan terhadap informan dilakukan secara sengaja (purposive) dan jumlahnya tidak ditentukan. Penetapan informan ini dilakukan dengan menggunakan teknik bola salju (snowball) kepada Ketua HIPOCI dan pihak CSR PT Tirta Investama.

Data yang digunakan dalam penelitian ini terdiri dari data primer dan data sekunder. Data primer diperoleh langsung dari lapang melalui survei dengan menggunakan kuesioner, wawancara mendalam dengan informan dan pengamatan. Data sekunder diperoleh dari dokumen-dokumen tertulis di kecamatan, dan PT Tirta Investama.
Selain itu juga diperoleh dari buku, UndangUndang, dan jurnal-jurnal hasil penelitian terkait modal sosial, pembangunan keberlanjutan, CSR, dan data monografi serta profil desa.

Data primer kuantitatif dikumpulkan melalui wawancara terstruktur kepada responden dengan menggunakan daftar pertanyaan (kuesioner). Data primer kualitatif dikumpulkan melalui (indepth interview) wawancara mendalam, melalui metode partisipatif dengan menggunakan teknik Focus Group Discussion (FGD), dan catatan harian lapang.

Pengolahan data dalam penelitian ini menggunakan tabel frekuensi, tabulasi silang, dan model korelasi rank spearman untuk mengukur korelasi antara tingkat jejaring sosial dengan tingkat keberlanjutan kelembagaan. Teknik korelasi ini dilakukan untuk mencari hubungan dua variabel bila data kedua variabel tersebut berbentuk ordinal atau berjenjang dan dapat berasal dari sumber yang tidak sama.

Dasar pengambilan keputusan dalam uji korelasi spearman yaitu jika nilai signifikansi $<0.05$ maka dapat disimpulkan bahwa terdapat korelasi yang signifikan antara variabel yang dihubungkan. Sebaliknya, jika nilai signifikansi $>0.05$ maka dapat disimpulkan bahwa tidak terdapat korelasi yang signifikan antara variabel yang dihubungkan.

\section{HASIL DAN PEMBAHASAN}

\section{Gambaran HIPOCI PT Tirta Investama}

Grup Aqua telah berdiri sejak tahun 1973 dengan nama PT Golden Mississippi. Pada tahun 1989 berubah nama menjadi PT Aqua Golden Missisippi. Grup Aqua hingga saat ini terdiri dari PT Aqua Golden Missisippi, PT Tirta Investama, dan PT Tirta Sibayakindo yang semuanya berlokasi di Indonesia, serta Ibic Bhd. Ltd. yang berlokasi di Brunei Darussalam. Pada tanggal 4 September 1998, terjadi aliansi strategis PT Tirta Investama dengan DANONE, dimana DANONE, kelompok usaha multinasional yang berpusat di Paris, Perancis melalui DANONE Asia Holding Pte.Ltd bergabung ke PT Tirta Investama sebagai minority shareholder. Selanjutnya PT Tirta Investama, PT Aqua Golden Mississippi dan PT 
Tirta Sibayakindo sepakat untuk bersinergi sebagai Grup AQUA.

Grup Aqua mempraktikkan tanggung jawab sosial sejak 1972 yang memiliki pemikiran menjalankan bisnis yang mengedepankan keseimbangan antara keberhasilan ekonomi dan kemajuan sosial. Pada tahun 2006, Grup Aqua menciptakan Aqua Lestari sebagai payung inisiatif keberlanjutan dengan menggunakan prinsip-prinsip dasar dari Danone Way, ISO 26000, dan Global Reporting Initiative sebagai rujukan. Aqua Lestari memiliki 4 pilar, yaitu: 1) Pelestarian Air dan Lingkungan; 2) Praktik Perusahaan Ramah Lingkungan; 3) Pengelolaan Distribusi Produk; 4) Pelibatan dan Pemberdayaan Masyarakat.

Dilatarbelakangi semakin tidak terkendalinya penggunaan bahan kimia untuk pupuk dan pestisida, AQUA Grup menyelenggarakan program pertanian berkelanjutan, dengan mengedepankan praktik partisipatoris. Fokus pelaksanaan program disesuaikan dengan konteks wilayah, dan metode yang dipilih adalah sistem pertanian terpadu atau Integrated Farming System (IFS). Dampak yang diharapkan adalah perubahan perilaku petani dalam mengolah lahan secara berkelanjutan, memproduksi pupuk organik, serta pestisida dan agensi hayati secara mandiri, sehingga melepaskan ketergantungan petani terhadap pupuk kimia dan pestisida.

\section{HIPOCI}

HIPOCI atau Himpunan Petani Organik Cianjur Indonesia berdiri sejak 5 Oktober 2011. HIPOCI merupakan lembaga resmi yang disahkan di Pengadilan Negeri Cianjur dengan nomor: W11. U11. PR7610.01/III/2012. HIPOCI merupakan kelompok tani lokal yang peduli dengan pertanian yang sehat. HIPOCI merupakan kumpulan kelompok petani organik. HIPOCI juga memiliki unit usaha dibidang Peternakan Domba, Kompos, KWT (Kelompok Wanita Tani), Pemuda Tani, UMKM, dan Ayam Pelung.

Sesuai dengan IFS, HIPOCI memiliki sistem pertanian yang terintegrasi. Petani organik mendapatkan pupuk organik dari unit usaha kompos dan KWT. Unit usaha kompos mendapatkan kotoran kambing dari peternakan domba. Anggota KWT merupakan istri dari petani yang diberdayakan untuk mengumpulkan sisa sampah dapur dan daun-daun untuk dijadikan POC (Pupuk Organik Cair). Pemuda Tani dilibatkan dalam memilah beras dan mengemas beras dalam kemasan $5 \mathrm{~kg}$ untuk siap dijual. Produk pertanian HIPOCI selain beras, KWT diberdayakan untuk membuat cemilan berbahan dasar beras. Skema sistem pertanian terpadu HIPOCI seperti pada Gambar 2.

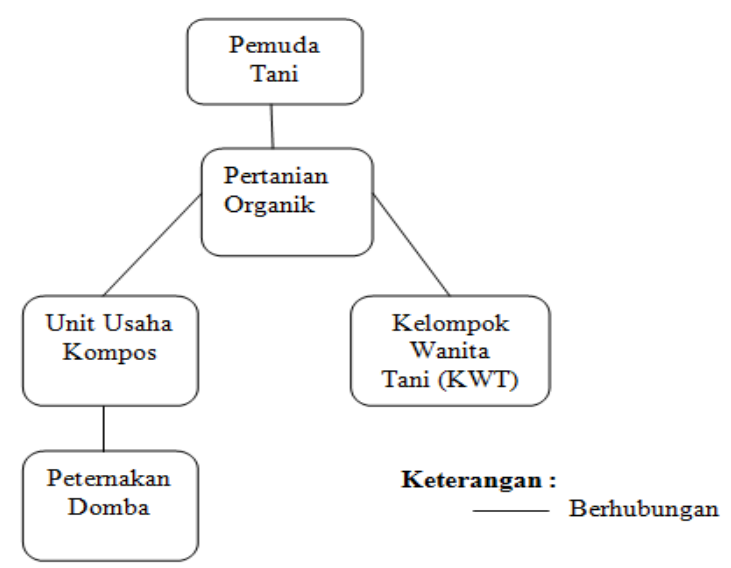

Gambar 2 Skema sistem pertanian terpadu HIPOCI

\section{Tingkat Jejaring Sosial}

Analisis tingkat jejaring sosial HIPOCI melihat seberapa luas jejaring yang terjalin dengan pemangku kepentingan. HIPOCI memiliki kategori jejaring sosial yang luas. Tingkat jejaring sosial dilihat berdasarkan tripologi modal sosial, yaitu: 1) social bonding, 2) social bridging, dan 3) social linking. Modal sosial yang ada pada HIPOCI di Kecamatan Gekbrong merupakan interaksi yang dibangun pada kehidupan sehari-hari dengan sesama petani organik dan anggota HIPOCI.

Social Bonding HIPOCI berada pada tingkat tinggi. Kecenderungan responden menyatakan anggota HIPOCI menjaga hubungan antar anggota dengan baik dan saling bergotong royong. Hubungan ini terjalin untuk saling berbagi pengalaman ketika ada masalah dalam produksi. Anggota akan bertanya pada anggota lain dan berdiskusi tentang permasalahan seperti produksi tani, permodalan, dan masalah hama. 
Social Bridging HIPOCI berada pada tingkat sedang. Hubungan HIPOCI adalah dengan kelompok dan petani lain untuk meningkatkan produksi beras. HIPOCI mampu memproduksi beras organik sebanyak 10 ton per musim, sedangkan pasar memerlukan 20 ton per bulan. Hal ini menjadikan HIPOCI bekerjasama dengan petani lain seperti dengan petani Cibeber, AlIkhwan, dan Gapoktan Mekar Tani Sukabumi, untuk memenuhi permintaan pasar. Kerjasama yang dijalani oleh HIPOCI selain beras organik adalah beras sehat. Beras sehat merupakan beras yang diproses dengan dua tahap, yaitu tahap secara organik dan non organik. Cara ini dilakukan untuk petani yang ingin memproduksi beras organik namun belum mampu mengikuti cara-cara organik.

Social Linking dilihat dari melalui hubungan yang terjalin antara petani dengan instansi luar yang memiliki derajat lebih tinggi seperti CSR, Pemerintah, dan pihak lain. Social Linking berada pada tingkat sedang. Social Linking Perusahaan dengan jumlah responden pada kategori sedang. Perusahaan membantu petani dalam hal pelatihan, produksi hingga pemasaran produk HIPOCI. Perusahaan PT Tirta Investama datang pada tahun 2011 untuk menerapkan program di Kecamatan Gekbrong karena kedekatan lokasi dengan perusahaan. Keinginan untuk menerapkan kelompok yang berbeda dan berkelanjutan, mendorong masyarakat dengan perusahaan bersama-sama membuat program pertanian organik dan membuat organisasi yang bernama Himpunan Pertanian Organik Cianjur Indonesia yang disingkat menjadi HIPOCI. Social Linking pemerintah berada pada tingkat sedang. Pemerintah memberikan bantuan berupa pelatihan. Kerjasama yang terjalin dengan pemerintah adalah dengan Koperasi, pelatihan perdagangan (UMKM), pelatihan Tax Amnesti, dan Kehutanan. Dinas Koperasi pernah memberikan sertifikasi halal sebagai label bahwa beras dari HIPOCI halal untuk dikonsumsi. Pemerintah dinilai hanya memberikan pelatihan saja, jarang memberikan bantuan lain. Hal ini terkait dengan kerjasama antar pemerintah dengan perusahaan yang menjadi bentuk tanggung jawab CSR perusahaan. Social Linking pihak lain berada pada tingkat sedang merupakan hubungan pihak luar yang datang ke HIPOCI baik yang didatangkan oleh perusahaan maupun yang datang berdasarkan informasi lain.
Pihak yang dibantu oleh perusahaan seperti mendatangkan ibu-ibu AHS dan mengajak HIPOCI untuk study banding di luar kota. Perusahaan mendatangkan ibu-ibu binaan program CSR Aqua untuk datang ke desa dalam rangka mengenal lebih dekat dengan produk beras organik yang selama ini mereka jual. Ibuibu AHS diajak untuk mengenal warga dan petani organik. Selain itu, ibu-ibu AHS diajak untuk terjun langsung belajar di sawah dengan tujuan melihat sulitnya proses yang dilalui oleh para petani agar menjadi beras organik yang selama ini dijual. Perusahaan pernah mendatangkan blogger dari Bandung dan blogger lainnya untuk mengenal lebih dekat dengan petani. Kegiatan blogger hampir sama dengan kedatangan ibu-ibu AHS. Hasil dari kunjungan blogger akan di bagikan pada masingmasing blog mereka.

Pihak lain yang datang ke HIPOCI berasal dari berbagai latar belakang. Selain blogger, HIPOCI pernah diliput oleh stasiun televisi, yaotu DAAI TV dan Kompas Media yang meliput tentang sistem pertanian HIPOCI yang dinilai baik sebagai inspirasi masyarakat terkait pertanian organik. HIPOCI sering kedatangan sekolah sebagai tempat pembelajaran dan HIPOCI pernah kedatangan tamu sebanyak 24 Negara yang diadakan oleh Cifor $\mathrm{C} 4$ yang bertujuan untuk study banding. Komunitas ini merupakan komunitas internasional yang peduli dengan lingkungan. Mereka mengunjungi pertanian organik, melihat saluran air, bermain di kebun teh, dan kegiatan lainnya. Selain itu, HIPOCI juga sering dikunjungi oleh berbagai perusahaan seperti migas sebagai tempat pembelajaran program CSR yang dapat dikategorikan berhasil. Pada tanggal 10-14 Agustus 2016 yang berlokasi di Bandung, HIPOCI diundang untuk mengisi stand acara Koperatif Fair. Acara tersebut rutin dilakukan setiap tahun sebagai bentuk pemasaran produk-produk lokal.

Pihak luar dari sekolah, universitas, dan instansi lain sering datang ke HIPOCI dengan tujuan untuk memberikan pelatihan kepada anggota HIPOCI. Pelatihan yang diajarkan seperti memilih benih yang baik, pelatihan pembasmian hama secar organik, pelaltihan menejem tani, dan pelatihan lainnya.

\section{Keberlanjutan Kelembagaan}


Analisis tingkat keberlanjutan kelembagaan petani organik HIPOCI melihat seberapa sejauh mana program HIPOCI berjalan meskipun pemangku kepentingan tidak lagi terlibat. Pada bagian pembahasan ini akan dibahas kapasitas kelembagaan, insentif kelembagaan, dan perencanaan bersama. Tingkat keberlanjutan kelembagaan berada pada tingkat tinggi. Peran ketua membesarkan nama HIPOCI didukung oleh anggota yang menjalankan tugas secara baik. Ketua memiliki peran yang cukup tegas. Ketua mampu mengumpulkan anggota untuk hadir acara rapat dan pelatihan. Anggota yang belum hadir pada acara akan saling mengingatkan untuk datang dengan cara menelpon anggota tersebut. Ketua HIPOCI memiliki peran dalam menjalin hubungan jejaring yang luas. Ketua mencari jalan mendapatkan bantuan di luar perusahaan dan pemerintah. HIPOCI memiliki nama yang cukup terkenal. Keberadaannya telah dikenal berbagai pihak dari mulai pelajar, media massa, dan perusahan. HIPOCI mendapatkan bantuan berupa pelatihan. Hal ini di manfaatkan oleh petani untuk mendapatkan ilmu dan memecahkan permasalahan yang dihadapi.

Keberlanjutan kelembagaan HIPOCI berada pada tingkat tinggi. Kapasitas kelembagaan ketua mampu menjadi sosok pemimpin yang mengayomi anggota sehingga anggota mempunyai keterbukaan ketika ditemukan masalah. Anggota juga dapat bekerja sesuai dengan tugas yang diberikan oleh ketua. Anggota mampu bekerjasama dengan sesama anggota lain dan menyelesaikan masalah secara mandiri. Petani mengaku lebih senang berkumpul pada acara non formal seperti ketika ngopi dan ngerokok bareng karena lebih santai dan terbuka. Petani sering menemukan beberapa permasalahan. Petani biasanya akan berkumpul untuk berdiskusi bertukar pikiran. Permasalahan yang tidak dapat dipecahkan akan di tampung dan didiskusikan dengan ketua, lalu akan dibuat forum di sekretariat agar permasalahan dapat ditukarkan dengan petani lainnya. HIPOCI juga sering kedatangan tamu dari berbagai pihak untuk memberikan pelatihan. Pelatihan ini di manfaatkan para petani untuk berdiskusi tentang permasalah yang belum terpecahkan baik pada diskusi santai maupun di forum.

Insentif Kelembagaan berada pada tingkat tinggi. Insentif merupakan pemberian hadiah kepada HIPOCI sebagai bentuk bantuan untuk mendorong petani meningkatkan produksinya. Pemberian insentif dapat berupa material (berupa modal, barang, upah, dan sejenisnya) maupun non material (berupa pelatihan, penghargaan, dan lainnya). HIPOCI tidak pernah mendapatkan insentif berupa modal dari perusahaan maupun pemerintah. Suatu perusahaan pernah datang untuk menawarkan modal, namun hingga penelitian ini selesai, perusahaan tersebut tidak kunjung datang. Perusahaan mengaku tidak memberikan insentif dalam bentuk modal agar mencegah pengaliran dana yang tidak tepat. Perusahaan lebih memilih membangun beberapa fasilitas seperti rumah produksi, memberikan alat produksi seperi alat penggiling, pemisah gabah, sealer dan vacum, kantor sekretariat, dan motor Viar sebanyak 3 unit. Pemerintah dinilai hanya memberikan pelatihan saja kepada HIPOCI. HIPOCI pernah mengajukan pinjaman modal. Kendala HIPOCI untuk menerima program pemerintah adalah lembaga ini bukan merupakan GAPOKTAN. Pemerintah hanya membantu binaannya, yaitu GAPOKTAN.

Perencanaan bersama berada pada tingkat tinggi. Anggota HIPOCI dilibatkan dalam perencanaan bersama untuk menentukan kebutuhan anggota petani. Anggota mampu memberikan pendapat, kritik dan memutuskan program. Perencanaan bersama dilaksanakan untuk menentukan kebutuhan petani yang masih belum terpenuhi. Anggota memberikan pendapat sesuai dengan permasalahan yang dihadapinya. Lalu anggota akan memutuskan bersama program selanjutnya. Pada saat pengambilan data, peneliti melihat ketua memberikan peran secara langsung kepada anggota. Ketua berdiskusi terkait programprogram baru yang ditawarkan. Program dimusyawarahkan agar sesuai dengan permasalahan dan kebutuhan.

\section{Analisis Hubungan Tingkat Jejaring Sosial Dengan Tingkat Keberlanjutan Kelembagaan}

Terdapat hubungan antara tingkat jejaring sosial dengan tingkat keberlanjutan kelembagaan. Tingkat jejaring sosial dan tingkat keberlanjuan kelembagaan berada pada tingkat rendah. Tingkat jejaring sosial berada pada tingkat sedang, persentase tingkat keberlanjuan kelembagaan berada pada tingkat sedang. Tingkat jejaring sosial berada pada tingkat 
sedang, persentase tingkat keberlanjuan kelembagaan berada pada tingkat tinggi. Tingkat jejaring sosial berada pada tingkat luas dan keberlanjutan kelembagaan pada tingkat sedang. Tingkat jejaring sosial berada pada tingkat luas dan persentase tingkat keberlanjuan kelembagaan pada tingkat tinggi. Jadi dapat disimpulkan, jika jejaring sosial luas maka tingkat keberlanjutan kelembagaan tinggi. Hal tersebut menyatakan hubungan antara tingkat jejaring sosial dengan tingkat keberlanjutan kelembagaan mempunyai hubungan yang kuat.

Hasil uji korelasi rank spearman menunjukan bahwa nilai koefesien korelasi sebesar +0.520 berarti berada pada selang koefisien korelasi 0.61 sampai 0.80 artinya: korelasi tinggi. Maka hubungan antara tingkat jejaring sosial dalam tingkat keberlanjutan kelembagaan mempunyai hubungan positif yang tinggi. Selain itu nilai probabilitas 0.008 lebih kecil dari 0.05 maka dapat disimpulkan terdapat korelasi yang signifikan antara tingkat jejaring sosial dalam tingkat keberlanjutan kelembagaan. Hal ini menunjukan bahwa tingkat jejaring sosial HIPOCI menjadi penentu tingkat keberlanjutan kelembagaan.

\section{Analisis Modal Sosial Dalam Keberlanjutan Kelembagaan}

Modal sosial seperti yang telah diketahui terdiri dari tiga komponen yaitu norma, kepercayaan, dan jejaring sosial. Penelitian ini memfokuskan modal sosial pada jejaring sosial. Hal ini karena jejaring sosial telah mencakup dua komponen modal sosial lainnya. Jejaring sosial terjadi karena adanya kepercayaan dan norma yang ada pada masyarakat. Pada hasil uji korelasi rank spearman sebelumnya, didapat hasil bahwa terdapat hubungan yang signifikan antara jejaring sosial dalam keberlanjutan kelembagaan. Modal sosial yan terdapat pada HIPOCI antara lain :

1. Modal sosial melekat pada anggota HIPOCI sebelum terbentuk. Masyarakat sering bergotong royong setiap kegiatan. Masyarakat memiliki rasa tanggung jawab untuk mengingatkan satu sama lain akan tugas dan ikut serta dalam kegiatan yang akan dilaksanakan.

2. Modal sosial berupa kepercayaan menjadi modal awal terbentuknya jaringan yang dimiliki HIPOCI. HIPOCI percaya kepada perusahaan untuk menerapkan program di kecamatan Gekbrong. HIPOCI percaya perusahaan akan memberikan perubahan baik pada petani dan melepas dari ketergantungan tengkulak yang merugikan.

3. Modal sosial berupa norma atau aturan mempunyai peran penting dalam mengontrol sistem bertani organik. Sistem tani organik memiliki aturan yang harus ditaati, yaitu petani menanam varietas Ciherang, menggunakan pupuk organik berupa pupuk kandang dan pupuk cair, menuliskan kegiatan bertani pada Dokitsu, dan memiliki kesepakatan harga jual ke RMU sesuai MOU. HIPOCI juga menjunjung tinggi kebudayaan yang melekat di masyarakat. Petani mengadakan kegiatan tanam raya dan panen raya. Hasil dari penjualan beras sebagian digunakan untuk kegiatan amal seperti memberi santunan pada anak yatim.

\section{SIMPULAN DAN SARAN}

\section{Simpulan}

Modal Sosial dalam Keberlanjutan Kelembagaan petani organik HIPOCI Kecamatan Gekbrong, Kabupaten Cianjur, Jawa Barat, dapat disimpulkan berperan sebagai penjaga keberlanjutan HIPOCI dalam mengakses informasi, menyelesaikan masalah, meningkatkan produksi, meningkat eksistensi, dan memperluas promosi.

1. Tingkat jejaringan sosial yang terdapat pada HIPOCI adalah luas. Jejaring sosial HIPOCI antara lain, 1) Social Bonding, hubungan yang terjalin pada social bonding adalah dengan petani organik dan anggota HIPOCI; 2) Social Bridging, hubungan yang dijalin merupakan hubungan secara horizontal, petani organik HIPOCI menjalin hubungan dengan petani Cibeber, Al-Ikhwan, dan Gapoktan Mekar Tani Sukabumi; dan yang terakhir 3) Social Linking, hubungan yang dijalin HIPOCI secara vertikal, yaitu perusahaan, pemerintah, dan pihak lain.

2. Tingkat keberlanjutan kelembagaan yang terdapat pada HIPOCI adalah tinggi. Tingkat keberlanjutan kelembagaan terdiri atas 3 faktor, yaitu 1) Kapasitas Kelembagaan berada dikategori tinggi 2) Insentif Kelembagaan berada dikategori tinggi. HIPOCI mendapat bantuan dari perusahaan 
berupa alat produksi tani, penggilingan, motor Viar sebanyak 3 unit, gedung sekretariat, gudang produksi, dan pelatihan. HIPOCI mendapat bantuan dari pemerintah berupa pelatihan, label nilai gizi di kemasan beras, dan penghargaan sebagai pusat beras sehat. HIPOCI mendapat bantuan dari pihak lain berupa pelatihan untuk mendapat pengetahuan pertanian dan eksistensi HIPOCI; dan yang terakhir 3) Perencanaan Bersama berada dikategori tinggi. Petani memberikan ide, saran, dan kritik saat perencaaan bersama.

3. Terdapat hubungan positif yang tinggi antara tingkat jejaring sosial dengan tingkat keberlanjutan kelembagaan. HIPOCI memiliki hubungan jejaring sosial dengan berbagai pemangku kepentingan.

\section{Saran}

Berdasarkan hasil penelitian, maka terdapat beberapa saran yang penulis ajukan dan sekiranya menjadi bahan masukan untuk pengembangan jejaring sosial dalam meningkatkan keberlanjutan kelembagaan. Modal sosial telah melekat kuat di HIPOCI. HIPOCI memiliki hubungan yang kuat pada social bonding, namun hal ini tidak demikian pada social linking. Keberlanjutan kelembagaan HIPOCI pada kapasitas kelembagaan, ketua berperan aktif dalam memberikan peran anggota sesuai tanggung jawab. Ketua juga mampu mencari jaringan baru untuk memperluas jaringan. Berdasarkan hasil penelitian, perusahaan belum maksimal dalam memfasilitasi HIPOCI untuk menjalin jejaring sosial secara vertikal. Modal sosial dan lingkungan di HIPOCI belum didukung dengan modal ekonomi. HIPOCI tidak memiliki kekuatan dalam bersaing di pasar. Upaya yang dapat dilaksanakan oleh perusahaan adalah memfasilitasi HIPOCI untuk mendapatkan modal ekonomi dengan menjadi penjamin.

\section{DAFTAR PUSTAKA}

ISO 26000. 2010. Guidance on Social Responsibility. [Internet]. [diunduh pada 5 Mei 2016]. Dapat diunduh dari http://webstore.ansi.org/RecordDetail.aspx?s $\mathrm{ku}=\mathrm{ISO}+26000 \% 3 \mathrm{a} 2010$
[UU]. Undang-Undang Nomor 40 Tahun 2007 Temtang Perserian Terbatas. [Internet]. [diunduh pada 3 Mei 2016]. Dapat diunduh dari

http://www.hukumonline.com/pusatdata/detai 1/26940/node/70/uu-no-40-tahun-2007perseroan-terbatas

Anantanyu S. 2009. Partisipasi Petani dalam Meningkatkan Kapasitas Kelembagaan Kelompok Petani (Kasus di Provinsi Jawa Tengah). [Disertasi]. Bogor (ID): Institut Pertanian Bogor. Anantanyu S. 2011. Kelembagaan Petani: Peran dan Strategi Pengembangan Kapasitasnya. SEPA: Vol NO.2 Februari 2011: 102-109.

Aqua. 2012. Laporan Keberlanjutan 20112012.[Internet]. [diunduh pada 4 Februari 2017]. Dapat diunduh dari aqua.com/uploads/files/Sustainability\%20R ep

ort/SR\%20Aqua.pdf

Arsyad I. 2015. Membangun Jaringan Sosial dan Kemitraan. Jakarta Pusat: (ID). Kementrian Desa, Pembangunan Daerah Tertinggal, dan Transmigrasi Republik Indonesia:

Coleman J. 1999. Social Capital in the Creation of Human Capital. American Journal of Sociology. [Internet]. [Diunduh pada 05 Oktober 2016]. Vol 94 : S95-S120. Dapat diunduh dari http://www.jstor.org/stable/2780243

Cox, E. 1995. A Truly Civil Society. [Internet]. [Diunduh pada 12 Oktober 2016] http://www.australianhumanitiesreview.org/ archive/issue1-feb-mar-96/cox/cox.1.html

Esman MJ. "Unsur-unsur dari Pembangunan Lembaga" dalam Pembangunan Lembaga dan Pembangunan Nasional: dari Konsep ke Aplikasi. Editor J.W. Eaton. Jakarta (ID): UI Press.

Fauzi A dan Oxtavianus A. 2014. Pengukuran Pembangunan Keberlanjutan di Indonesia. [internet]. 19.20 [diunduh pada 2 Maret 2016]. Volume 30, No.1. Dapat diunduh dari

http://ejournal.unisba.ac.id/index.php/mimb ar/article/view/445/759\#.Vugy5-J97Dc

Hasbullah J. 2006. Social Capital (Menuju Keunggulan Budaya Manusia Indonesia). Jakarta (ID): MR-United Press Jakarta.

Lubis H dan Huseini M. 2009. Pengantar Teori Organisasi Suatu Pendekatan Makro. Jakarta (ID): UI 
Nasdian FT. 2014. Pengembangan Masyarakat. Jakarata (ID): Yayasan Pustaka Obor Indonesia.

Rudito B dan Melia F 2013. CSR (Corporate Social Resposibility). Rekayasa Sains: Bandung.

Woolcock MM. 2001. The place of social capital in understanding social and economic outcomes. Isuma: Canadian Journal of Policy Research.[Internet]. [diunduh pada $20 \mathrm{Mei}$ 2016]. Vol 2 (1) : 11 - 17. Dapat diunduh dari http://www.socialcapital.net/docs/The $\% 20$ Place $\% 20$ of $\% 20$ Soci al\%20Capital.pdf. 